\title{
Confirmation of soybean plastid rRNAs by formaldehyde denaturing agarose gel electrophoresis
}

\author{
Y.Q. Zhu ${ }^{1,2}$, Y. Zheng ${ }^{1,2}$, H.B. Chen ${ }^{1,2}$ and L.Q. Huang ${ }^{1,2}$ \\ ${ }^{1}$ School of Life Sciences, Tsinghua University, Beijing, China \\ ${ }^{2}$ The Shenzhen Key Laboratory of Gene and Antibody Therapy, \\ Center for Biotech and BioMedicine, \\ State Key Laboratory of Health Sciences and Technology, \\ Division of Life and Health Sciences, \\ Graduate School at Shenzhen, Tsinghua University, \\ Shenzhen, Guangdong, China
}

Corresponding author: L.Q. Huang

E-mail: huanglq@sz.tsinghua.edu.cn

Genet. Mol. Res. 13 (4): 8640-8644 (2014)

Received March 27, 2013

Accepted March 11, 2014

Published October 27, 2014

DOI http://dx.doi.org/10.4238/2014.October.27.3

\begin{abstract}
Owing to their prokaryotic origin, plastid rRNAs are mainly $23 \mathrm{~s} / 16 \mathrm{~s} / 5 \mathrm{~s}$ rRNAs. We present a novel plant RNA isolation method in this paper. Also, not only the eukaryotic $28 \mathrm{~s}(26 \mathrm{~s}, 25 \mathrm{~s}) / 18 \mathrm{~s}$ rRNAs but the prokaryotic 26s/23s rRNAs as well were demonstrated in a single sample for the first time by formaldehyde denaturing agarose gel electrophoresis.
\end{abstract}

Key words: Plant; Soybean; Plastid rRNAs; Gel electrophoresis 


\section{INTRODUCTION}

According to the endosymbiosis theory, plastids originated from eubacteria-like cells that had invaded and then lived within primitive eukaryotic hosts (Bonen and Doolittle, 1975; Schwarz and Kössel, 1980). Gradually, they became an important group of plant cellular organelles with essential functions (McFadden, 2001). All plastids such as the chloroplast, amyloplast, chromoplast, and leucoplast were initially originated from proplastids during cell differentiation (Pyke, 1999).

Different methods, including denaturing salts such as guanidinium (guanidine salts) (Chomczynski and Sacchi, 1987)/urea (Almarza et al., 2006), acid phenol (Geuna and Hartings, 1998), detergents such as cetyltrimethylammonium bromide (CTAB) (Chang et al., 1993; Békésiova et al., 1999; Kiefer et al., 2000)/sodium dodecyl sulfate (SDS) (Newbury and Possingham, 1977; Wan and Wilkins, 1994) and hot borate (Manning, 1991), have been developed to purify plant RNA. Formaldehyde denaturing agarose gel electrophoresis (Sambrook et al., 1989) is usually utilized to check RNA integrity. A high-quality plant RNA electrophoresis pattern always comprises two main 26s (25s) and 18s rRNA bands, plus a 5s rRNA band depending on the RNA isolation procedure. Here, we report a plant RNA isolation method, where not only the $26 \mathrm{~s} / 18 \mathrm{~s}$ rRNAs but the $23 \mathrm{~s} / 16 \mathrm{~s}$ rRNAs of a single sample were demonstrated by formaldehyde denaturing agarose gel electrophoresis. We also showed some degraded RNA electrophoresis patterns, which are usually considered as patterns of intact RNA samples.

\section{MATERIAL AND METHODS}

Approximately $500 \mathrm{mg}$ soybean seeds (at mature green stage) was thoroughly ground into fine powder in the presence of liquid nitrogen with a mortar and pestle. The frozen powder was quickly transferred to a 10 -mL tube containing $2.5 \mathrm{~mL}$ preheated $\left(\right.$ at $\left.65^{\circ} \mathrm{C}\right)$ homogenization solution (2\% CTAB, $1.5 \mathrm{M} \mathrm{NaCl}, 100 \mathrm{mmol}$ Tris, 20 mmol EDTA, pH 8.0, 2\% $\beta$-mercaptoethanol). The tube was vigorously shaken and then incubated at $65^{\circ} \mathrm{C}$ for $5 \mathrm{~min}$. The tube was spun at $14,000 \mathrm{rpm}$ for $2 \mathrm{~min}$ at room temperature. The supernatant was transferred to 2 new microfuge tubes. A 0.1 volume of $10 \mathrm{M} \mathrm{LiCl}$ was added to the supernatant. The tubes were inverted several times and then centrifuged at $14,000 \mathrm{rpm}$ for $30 \mathrm{~min}$ at $4^{\circ} \mathrm{C}$ to pellet RNA. The supernatant was completely decanted and the pellet resuspended with $100-200 \mu \mathrm{L}$ denaturing solution $(4.0 \mathrm{M}$ guanidinium thiocyanate, $25 \mathrm{mM}$ sodium citrate, $\mathrm{pH} 7.0,0.5 \%$ sodium $\mathrm{N}$-lauroyl sarcosine and $2 \% \beta$-mercaptoethanol). The supernatant was equally transferred to 2 fresh microfuge tubes labeled $\mathrm{A}$ and $\mathrm{B}$. Two volumes of $100 \%$ ethanol were added to tube $\mathrm{A}$ followed by centrifugation at $14,000 \mathrm{rpm}$ for $15 \mathrm{~min}$ at $4^{\circ} \mathrm{C}$. A 0.2 volume of $10 \mathrm{M} \mathrm{LiCl}$ was added to tube $\mathrm{B}$, which was then inverted several times and spun at $14,000 \mathrm{rpm}$ for $30 \mathrm{~min}$ at $22^{\circ} \mathrm{C}$. The supernatant of tube $\mathrm{B}$ was transferred to a new microfuge tube labeled C. Two volumes of $100 \%$ ethanol were added to tube $\mathrm{C}$, followed by centrifugation at maximum speed for $15 \mathrm{~min}$ at $4{ }^{\circ} \mathrm{C}$. The supernatant was discarded and the RNA pellets in the 3 labeled tubes washed with $0.5 \mathrm{~mL} 75 \%$ ethanol twice. The supernatant was discarded, the tubes spun briefly, and the residual supernatant aspirated. The pellets were air-dried at room temperature and dissolved in $20 \mu \mathrm{L}$ DEPC-treated water. The total RNAs of cultivated Escherichia coli DH5 $\alpha$ and Saccharomyces cerivisiae Y190 were also extracted as previously reported (Zhu et al., 2013). RNA samples of 3-12 $\mu \mathrm{L}$ were subjected to $1 \%(\mathrm{w} / \mathrm{v})$ formaldehyde denaturing $1.2 \%$ agarose gel electrophoresis to determine RNA integrity. 


\section{RESULTS AND DISCUSSION}

Because of excessive loading of samples, the rRNA bands of lanes 1 and 3 were ambiguous (Figure 1). When we reduced the RNA samples, the main rRNA bands turned out to be distinct (Figure 2A).

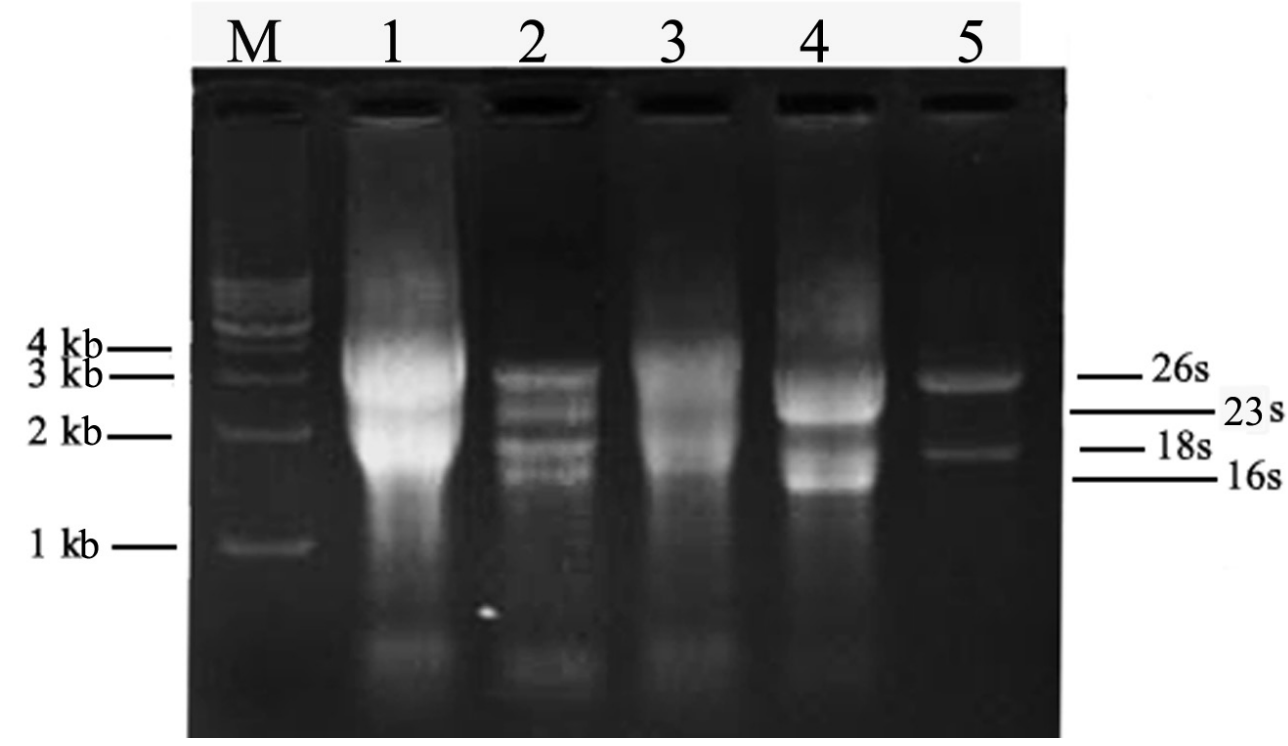

Figure 1. RNA integrity judged by formaldehyde denaturing agarose gel electrophoresis. Lane $M=1-\mathrm{kb}$ DNA ladder marker (TaKaRa, China); lane 1=RNA sample A; lane 2 = RNA sample B; lane 3=RNA sample C; lane 4 $=$ RNA extracts of $E$. coli DH5 $\alpha$; lane $5=$ RNA extracts of S. cerivisiae Y190.

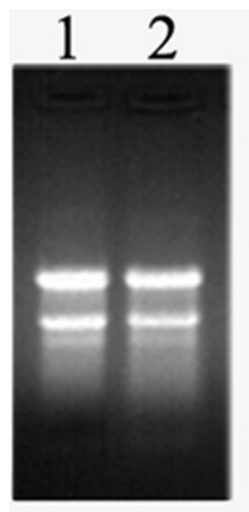

A

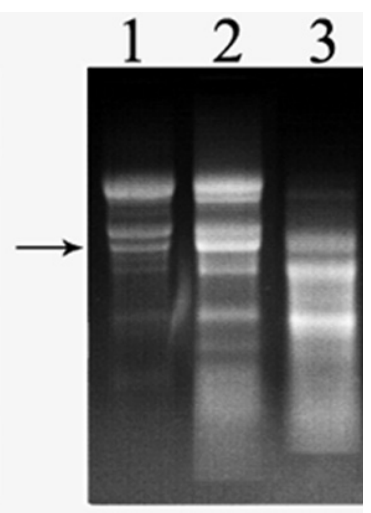

B

Figure 2. Intact and partially degraded RNA electrophoresis patterns. A. Lane $1=$ RNA sample A; lane $2=$ RNA sample C. B. Lane 1 = RNA extracts of young Litchi chinensis leaf purified by a modified hot borate method (Wu and $\mathrm{Liu}, 2004$ ); lane 2 = RNA extracts of young cotton leaf purified by a modified hot borate method (Wu and Liu, 2004); lane 3 = extracts of young cotton leaf purified by a modified hot borate method (Wan and Wilkins, 1994). 
The rRNA ratio $(26 \mathrm{~s} / 18 \mathrm{~s}, 23 \mathrm{~s} / 16 \mathrm{~s})$ is considered an essential measure of RNA intactness of the denaturing agarose gel electrophoresis test. Figure 1 (lane 4/lane 5) and Figure 2A showed that the respective $26 \mathrm{~s} / 23 \mathrm{~s}$ ribosomal RNA band intensity was approximately 1.5-2 times that of the corresponding $18 \mathrm{~s}$ or $16 \mathrm{~s}$ rRNA band. It indicated high RNA integrity. RNA sample B displayed 4 main sharp bands (Figure 1, lane 2). The sizes of the 4 bands corresponded to $26 \mathrm{~s}, 23 \mathrm{~s}, 18 \mathrm{~s}$, and $16 \mathrm{~s}$ rRNAs, and there were no other smaller bands appearing in the lane. Besides, RNA of sample $\mathrm{C}$, which was obtained from the supernatant of the precipitated RNA of sample B, was highly intact. Thus, we believe that RNA of sample B was intact, rather than degraded RNA fragments. Why were there 4 distinct rRNA bands in lane 2 (Figure 1)? We consider that the 26s/18s rRNAs are much more abundant than the 23s/16s rRNAs in plant cells. When the total RNAs prepared by the commonly used methods (as mentioned above) are analyzed by denaturing agarose gel electrophoresis, the $23 \mathrm{~s} / 16 \mathrm{~s}$ rRNAs are concealed by the $26 \mathrm{~s} / 18 \mathrm{~s}$ rRNAs, or the quantity of the $23 \mathrm{~s} / 16 \mathrm{~s}$ rRNAs is too little to be evident. Since we loaded $3 \mu \mathrm{L}$ RNA sample in lanes 1 and 3 and $12 \mu \mathrm{L}$ in lane 2 (Figure 1), the band intensity of lane 2 was a little weaker than that of lane 3 . Accordingly, it can be calculated that approximately $20 \%$ of the total RNAs were precipitated. The total RNAs including 26s/23s/18s/16s rRNA may be selectively precipitated by $\mathrm{LiCl}$ under the strong denaturing condition, which may eventually result in the comparative enrichment of the $23 \mathrm{~s} / 16 \mathrm{~s}$ rRNAs. This may be the possible reason that there were four distinct rRNA bands in lane 2 (Figure 1). According to their sizes, we believe that the four rRNA bands corresponded to 26s, 23s, 18s, and 16s rRNAs. This corroborates the presence of both eukaryotic and prokaryotic rRNAs in Glycine max L. soybean cells, which in turn may serve as evidence that plastids originated from prokaryotic cells.

In Figure 2B (lane 1), the band indicated by the arrow is usually considered 16s rRNA of an intact RNA sample. The bands were sharp and the 26s rRNA band intensity was twice that of the 18s rRNA band. But there were several weaker and smaller bands other than the band indicated by the arrow in the lane, and the 23s rRNA band was not detected. Therefore, the band indicated by the arrow as well as the smaller bands actually came from partially degraded 26s/18s rRNAs. This circumstance was more evident in lane 2. Lane 3 showed an electrophoresis pattern of RNAs that had undergone severe degradation (Figure 2B).

\section{REFERENCES}

Almarza J, Morales S, Rincon L and Brito F (2006). Urea as the only inactivator of RNase for extraction of total RNA from plant and animal tissues. Anal. Biochem. 358: 143-145.

Békésiova I, Nap JP and Mlynárová L (1999). Isolation of high quality DNA and RNA from leaves of the carnivorous plant Drosera rotundifolia. Plant Mol. Biol. Rep. 17: 269-277.

Bonen L and Doolittle WF (1975). On the prokaryotic nature of red algal chloroplasts. Proc. Natl. Acad. Sci. U. S. A. 72: 2310-2314.

Chang S, Puryear J and Caimey J (1993). A simple and efficient method for isolating RNA from pine trees. Plant Mol. Biol. Rep. 11: 113-116.

Chomczynski P and Sacchi N (1987). Single-step method of RNA isolation by acid guanidinium thiocyanate-phenolchloroform extraction. Anal. Biochem. 162: 156-159.

Geuna F and Hartings H (1998). A new method for rapid extraction of high quality RNA from recalcitrant tissues of grapevine. Plant Mol. Biol. Rep. 16: 61-67.

Kiefer E, Heller W and Ernst D (2000). A simple and efficient protocol for isolation of functional RNA from plant tissues rich in secondary metabolites. Plant Mol. Biol. Rep. 18: 33-39.

Manning K (1991). Isolation of nucleic acids from plants by differential solvent precipitation. Anal. Biochem. 195: 45-50. McFadden GI (2001). Chloroplast origin and integration. Plant Physiol. 125: 50-53. 
Newbury HJ and Possingham JV (1977). Factors affecting the extraction of intact ribonucleic acid from plant tissues containing interfering phenolic compounds. Plant Physiol. 60: 543-547.

Pyke KA (1999). Plastid division and development. Plant Cell 11: 549-556.

Sambrook J, Fritsch EF and Maniatis T (1989). Molecular Cloning: a Laboratory Manual. Cold Spring Harbor Laboratory Press, Cold Spring Harbor.

Schwarz ZS and Kössel K (1980). The primary structure of 16S rDNA from Zea mays chloroplast is homologous to E. coli 16S rRNA. Nature 283: 739-742.

Wan CY and Wilkins TA (1994). A modified hot borate method significantly enhances the yield of high-quality RNA from cotton (Gossypium hirsutum L.). Anal. Biochem. 223: 7-12.

Wu YT and Liu JY (2004). A modified hot borate method for efficient isolation of total RNA from different cottontissues. Cotton Sci. 16: 1002-7807.

Zhu YQ, Wu WJ and Xiao HW (2013). A generic plant RNA isolation method suitable for RNA-Seq and suppression subtractive hybridization. Genet. Mol. Res. 12: 5537-5546. 